\title{
PRIEŠ LAIKĄ PAGIMDŽIUSIŲ MOTERŲ PSICHINĖS BŪKLĖS VERTINIMAS
}

\author{
Andrius Jurènas ${ }^{1}$, Virginija Paliulytè $\dot{2}^{2,3}$ \\ ${ }^{1}$ Vilniaus universiteto Medicinos fakultetas, ${ }^{2}$ Vilniaus universiteto Medicinos fakulteto Akušerijos ir \\ ginekologijos klinika, ${ }^{3}$ Vilniaus universiteto ligoninè Santaros klinikos, Akušerijos ir ginekologijos \\ centras
}

Raktažodžiai: priešlaikinis gimdymas, psichinė būklè, nerimas, HAM-N.

\section{Santrauka}

Darbo tikslas: įvertinti prieš laiką pagimdžiusių moterų psichinę būklę ir nustatyti psichologo poreiki postnataliniu laikotarpiu.

Metodika: 2016 m. lapkriti - 2017 m. vasari Vilniaus universiteto ligonineje Santaros klinikose (VUL SK) Akušerijos ir ginekologijos centre atliktas prospektyvinis anoniminis anketinis tyrimas. İ tyrimą buvo įtraukta 51 prieš laiką pagimdžiusi moteris, jos buvo apklaustos pogimdyminèse palatose $1-3$ parą po gimdymo. Buvo vertinta gimdyvių psichinè būklè, atsižvelgiant ị demografinius duomenis, akušerinę anamnezę bei šio néštumo eigą. Psichiniam ir somatiniam nerimui vertinti naudota modifikuota, su gydytoju psichiatru bei gydytoju akušeriu-ginekologu aptarta Hamiltono nerimo skale (HAM-N). Duomenys apdoroti SPSS 20 programa. Patikimumas apskaičiuotas naudojant chi kvadrato testą $(\mathrm{p} \leq 0,05)$.

Rezultatai: 68,6 proc. $(\mathrm{n}=35)$ moterų patyre emocinių sukrètimų dèl priešlaikinio gimdymo. Didžiausią ịtaką bendrai psichinei būklei perinataliniu laikotarpiu turejo patirtas nerimas $(60,8$ proc., $(n=31)$, baimè $(13,7$ proc., $(\mathrm{n}=7)$, nemiga $(13,7$ proc., $(\mathrm{n}=7)$ ir itampa (11,8 proc., $(\mathrm{n}=6)$. Gimdyvių, vertintų pagal Hamiltono nerimo skalę, vidurkis buvo 10,45 balai ( $\mathrm{min}-$ 0 , max -28 balai). Psichinio nerimo vidurkis $-6,7$ balai, somatinio $-4,14$. 76,5 proc. $(n=39)$ motery turi lengvą nerimo sutrikimą (surinko iki 14 balų), 11,8 proc. $(\mathrm{n}=6)$ - vidutinio sunkumo (surinko 15 21 balą), 11,8 proc. $(\mathrm{n}=6)$ - stiprų nerimo sutrikimą (daugiau kaip 21 balą). 17,6 proc. $(n=9)$ moterų teigia, kad joms būtų reikalinga psichologo konsultacija pogimdyminiu laikotarpiu: 55,5 proc. $(n=5)$ gimdyviu
- kartą per savaitę, 44,5 proc. $(\mathrm{n}=4)$ - kas antrą dieną. Išvados. Net 23,6 proc. tiriamuju nustatytas vidutinio sunkumo ar stiprus nerimo sutrikimas. Tam tikri demografiniai rodikliai, akušerinès anamnezès veiksniai bei šio něštumo eigos padariniai turi reikšmingos įtakos atskiriems psichinio nerimo bei somatinio nerimo simptomams. Net 17,6 proc. tiriamujų norètu, kad joms būtų suteikta psichologo konsultacija po gimdymo.

\section{Ivadas}

Pagal Pasaulio sveikatos organizacijos pateikiamą apibrèžimą (PSO) priešlaikiniu gimdymu vadinamas toks gimdymas, kuris ịvyko nuo 22-os iki 37-os gestacijos savaitès pabaigos (36 sav. $+6 \mathrm{~d}$.), arba praejus mažiau nei $259 \mathrm{~d}$. nuo pirmos paskutinių moters menstruacijų dienos $(1,2)$. Jei tikslus néštumo laikas nèra žinomas, laikoma, kad gimdymas yra priešlaikinis, jei naujagimis sveria $\geq 500 \mathrm{~g} \mathrm{(3)}$.

Nuo 1990 iki 2005 m. Europoje priešlaikinių gimdymų padaugèjo 22 proc. Šią tendenciją lemia keletas veiksnių: daugeja daugiavaisių néštumų dèl pagalbinio apvaisinimo procedūrų, gimdo vis vyresnès moterys, kurios dažniau serga šalutinèmis ligomis, joms dažniau pasitaiko něštumo komplikacijų (5).

Priešlaikinis gimdymas yra dažniausia (75-80 proc.) perinatalinio mirtingumo ir sergamumo (ivairių neurologinių, regèjimo, klausos, motorinių ar psichinių problemų) priežastis visame pasaulyje, dẻl kurios $2010 \mathrm{~m}$. buvo prarasta $1,08 \mathrm{mln}$. gyvybiu 193 šalyse $(2,5)$.

Pirmieji moksliniai tyrimai, siekiantys suprasti streso poveikị něštumo eigai, prasidejo $1970 \mathrm{~m}$. (7). Skelbiama ne viena mokslinè publikacija, kuri įrodo, jog yra stiprus ryšys tarp nëštumo ir moters psichinès būklès. Bloga moters psichinè savijauta susijusi su daugeliu neigiamų pasekmių perinataliniu laikotarpiu: didejja persileidimų ar priešlaikinių gimdymų rizika, dažniau pasitaiko mažas naujagimių 
svoris, gali prasidèti hipertenzija ir depresija nèštumo metu ar po gimdymo (8-13). Motinų, turinčių nerimo sutrikimų ar sergančių komorbidine depresija, naujagimiai dažniau verkia, mažiau šypsosi, rečiau žaidžia, silpniau išreiškia mimikas (14).

Nepaisant to, kad vis daugiau demesio skiriama moters psichinei sveikatai perinataliniu laikotarpiu tiek akušerijos-ginekologijos, tiek psichiatrijos ar psichologijos mokslo literatūroje ir praktikoje, tačiau atlikta labai nedaug tyrimų, vertinančių prieš laiką pagimdžiusių moterų patirtis.

Anksčiau gimdymo termino pagimdžiusios moterys paprastai patiria didesnị stresą lyginant su laiku gimdžiusiomis moterimis (16). Jos daugiau jaudinasi, nerimauja, nes vaiko gimimas yra netikètas, neplanuotas, neretai tenka keisti ịprastinę gimdymo taktiką, naujagimis yra atskiriamas nuo mamos intensyvios terapijos skyriuje, tèvai jaučiasi bejejgiai kažką pakeisti ir yra išsigandę dèl vaiko sveikatos (5).

Darbo tikslai: 1. Ivertinti prieš laiką pagimdžiusių moterų psichinę būklę, atsižvelgiant ị demografinius rodiklius, akušerinę anamnezę, šio nèštumo eigą. 2 . Nustatyti psichologo poreiki postnataliniu laikotarpiu.

\section{Tyrimo medžiaga ir metodai}

2016 m. lapkriti - 2017 m. vasari Vilniaus universiteto ligonineje Santaros klinikose (VUL SK) Akušerijos ir ginekologijos centre atliktas prospektyvinis anoniminis anketinis tyrimas. I tyrimą buvo ịtraukta 51 moteris, jos buvo apklaustos pogimdyminėse palatose $1-3$ parą po gimdymo. Šiame darbe buvo vertinti demografiniai duomenys (amžius, šeiminė padètis, išsilavinimas, gyvenamoji vieta), akušerinè anamnezė (nèštumų skaičius, buvusių nèštumų, nesibaigusių gimdymu, priežastys, gimdymų skaičius, buvusių gimdymų baigtys, esamų vaikų sveikata), šio néštumo eiga (vaisių skaičius, nėštumo patologija, motinos ligos), gimdyvių psichinè būklè bei psichologo poreikis perinataliniu laikotarpiu. Psichinei būklei vertinti naudota modifikuota, su
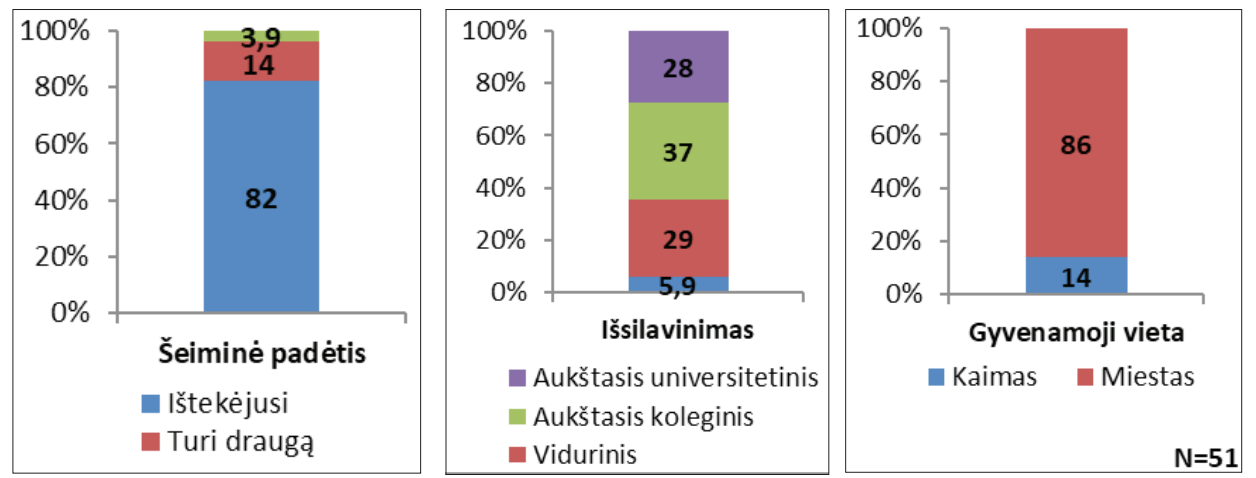

gydytoju psichiatru bei gydytoju akušeriu-ginekologu aptarta Hamiltono nerimo skalè (HAM-N), kuri leidžia įvertinti bendrą nerimą, psichinị nerimą ir somatinį nerimą. Pagal paciento atsakymus kiekvienas punktas vertinamas penkių balų skaleje nuo 0 iki 4 (17). Pasikonsultavus su gydytojais akušeriais-ginekologais, iš senosios Hamiltono nerimo skalès buvo atsisakyta vertinti lytinius ir šlapinimosi simptomus dèl néštumo ar gimdymo metu esančiu pokyčių urogenitalinėje sistemoje, kurie galètų iškreipti statistinès analizès rezultatus. Taip pat buvo atsisakyta vertinti elgesi pokalbio metu, nes dèl konfidencialumo bei gerbiant moters ramybę po gimdymo, anketa buvo paliekama palatoje, kad gimdyve, nejausdama streso bei įtampos, pati anonimiškai pasirinktų jai tinkantị atsakymą. 12 -os punktų ịvertinimui skiriami balai nuo $0 \mathrm{iki}$ 4: 0 reiškia, kad nèra simptomo, 1 - simptomo ryškumas silpnas, 2 - simptomas vidutiniškai ryškus, 3 - simptomas stipriai ryškus, 4 - simptomas labai stipriai ryškus, trukdantis funkcionavimui simptomas. Baigus testavimą, gauti punktų balai sudedami ir gaunamas bendras skalès rezultatas. Bendras modifikuotos HAM-N skalès rezultatas svyruoja nuo 0 iki 48. Šešių psichinio nerimo punktų rezultatas svyruoja nuo 0 iki 24 kaip ir somatinio nerimo punktų. Bendro rezultato vertinimas: iki 14 balų rodo lengvą nerimo sutrikimą, 15 21 balai rodo vidutinio sunkumo nerimo sutrikimą, per 21 balą - stiprų nerimo sutrikimą (17).

Duomenys apdoroti SPSS 20 programa. Duomenu patikimumas apskaičiuotas naudojant chi kvadrato testą $(\mathrm{p} \leq 0,05)$.

\section{Rezultatai}

Demografiniai duomenys. Šio tyrimo imtị sudarè 51 moteris, sutikusi anonimiškai dalyvauti tiriamajame darbe. Respondenčių amžiaus vidurkis - 27,57 $\pm 4,96$, amžiaus ribos - $17-38 \mathrm{~m}$. Detaliai demografiniai duomenys pavaizduoti 1 paveiksle.

Akušerinė anamnezė. 47,1 proc. $(\mathrm{n}=24)$ moterų tai buvo pirmas néštumas, 35,3 proc. $(\mathrm{n}=18)$ - antras, 11,8 proc. $(\mathrm{n}=6)$

1 pav. Prieš laiką pagimdžiusių moterų demografiniai duomenys 


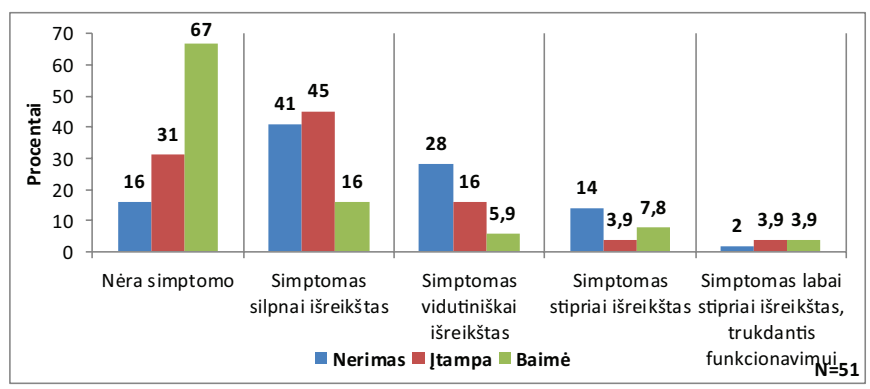

3 pav. Nerimo, ịtampos ir baimès simptomų vertinimas

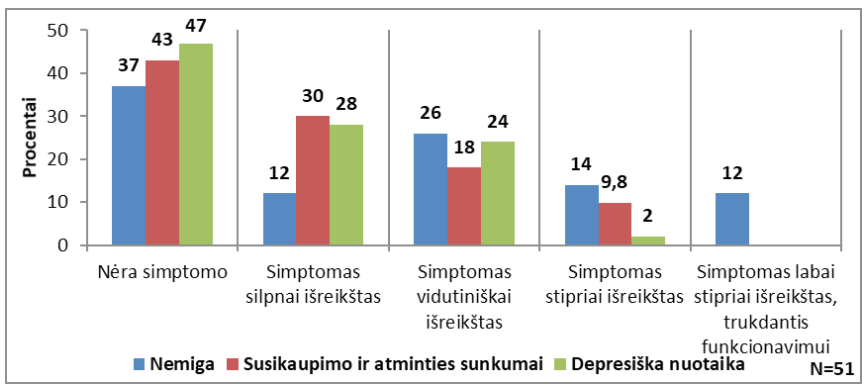

4 pav. Nemigos, susikaupimo ir atminties sunkumų bei depresinès nuotaikos vertinimas

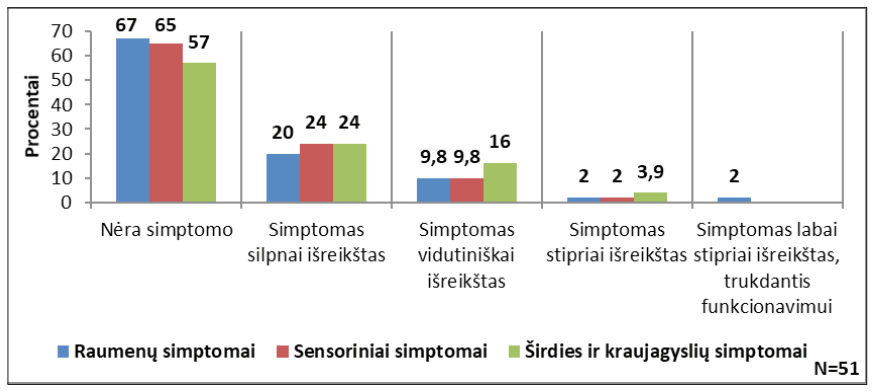

5 pav. Raumenų, sensorinių simptomų bei širdies ir kraujagyslių simntomu vertinimas

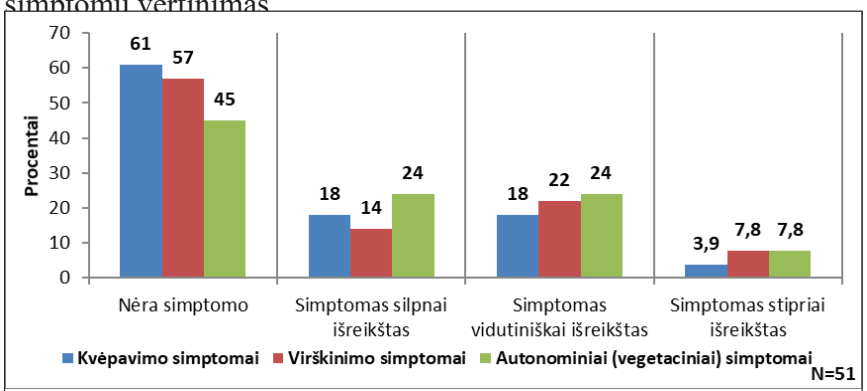

6 pav. Kvejpavimo, virškinimo bei autonominių (vegetacinių) simptomų vertinimas

- trečias, 2 proc. $(n=1)$ - penktas, 4 proc. $(n=2)$ - daugiau nei penktas. 33,3 proc. $(n=17)$ moterų jų ankstesni nëštumai nesibaigè gimdymu: 40 proc. $(n=8)$ tiriamujų dèl nėštumo

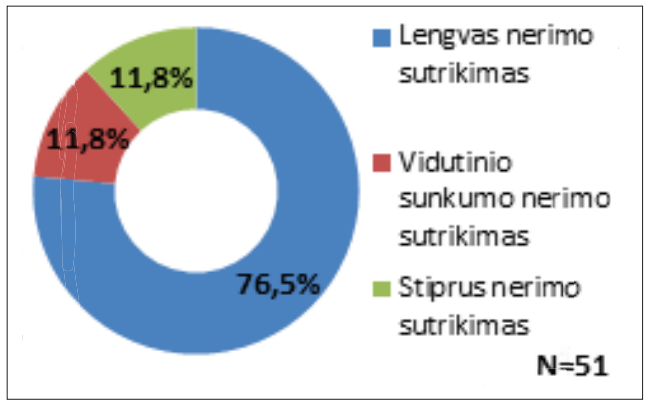

7 pav. Patirto nerimo ịvertinimas

nutraukimo, 35 proc. $(\mathrm{n}=7)$ dèl savaiminio persileidimo, 25 proc. $(\mathrm{n}=5)$ buvo nesivystantis néštumas. 70,6 proc. $(\mathrm{n}=36)$ moteru tai buvo pirmas gimdymas, 21,6 proc. $(\mathrm{n}=11)$ - antras, 3,9 proc. $(\mathrm{n}=2)$ - trečias, 2 proc. $(\mathrm{n}=1)$ - ketvirtas, 2 proc. $(\mathrm{n}=1)$ - šeštas. Dažniausios buvusių gimdymų baigtys pasiskirste taip: 52,9 proc. $(\mathrm{n}=9)$ vaikas gimè laiku, 29,4 proc. $(\mathrm{n}=5)$ gimè prieš laiką, 17,7 proc. $(n=3)$ gimė po gimdymo termino. Visų anksčiau gimdžiusių moterų vaikai gimè sveiki.

Šio néštumo eiga. 60,8 proc. $(n=31)$ respondenčių šis nèštumas buvo vienvaisis, 39,2 proc. $(n=20)$ - daugiavaisis. Dažniausia patologija, nustatyta šio nèštumo metu: 39,2 proc. $(n=20)$ moteru nustatyta gresiantis priešlaikinis gimdymas, 33,3 proc. $(n=17)$ - prieš laiką nutekejję vaisiaus vandenys, 31,4 proc. $(\mathrm{n}=16)$ - makšties uždegimas, 17,6 proc. $(\mathrm{n}=9)$ - šlapimo takų infekcija. 82,4 proc. $(\mathrm{n}=42)$ moterų pagimdè $30-36$ sav. \pm 6 d. naujagimius, 17,6 proc. $(\mathrm{n}=9) 22-30$ sav. naujagimius. $74,5$ proc. ( $n=38)$ gimdyvių žinojo, jog gimdymas grèsė anksčiau laiko. 5,9 proc. $(n=3)$ respondenčių nurodè, jog serga lètinèmis ligomis.

Psichinès būklès vertinimas. 68,6 proc. $(\mathrm{n}=35)$ moterų patyrè emocinių sukrètimų dèl priešlaikinio gimdymo. Paprašytos aprašyti, kaip jautèsi sužinojusios, jog gresia gimdymas prieš laiką, didžioji dalis respondenčių teige nerimavusios, kad gali neišnešioti vaiko, keletas patyrè didelị stresą ar net šoką, tik pavienès moterys buvo ramios. Gimdyvių žodžiais, labiausiai nerimą kẻlè pavojus vaiko gyvybei ir sveikatai, nežinia dèl ateities, pati gimdymo eiga bei nerimas, jog negalès būti kartu su savo vaiku.

Nerimą, kaip dažniausią būseną, kuri nedavè ramybès perinataliniu laikotarpiu, anketoje pasirinko 60,8 proc. $(\mathrm{n}=31)$ gimdyvių, 13,7 proc. $(\mathrm{n}=7)$ pažymèjo baimę, 13,7 proc. $(\mathrm{n}=7)$ - nemigą ir 11,8 proc. $(\mathrm{n}=6)$ - itampą ( 2 pav.).

Nerimas. 41,2 proc. $(\mathrm{n}=21)$ gimdyvių teigè patiriančios nerimą šiek tiek daugiau nei ịprastai, bet kontroliuojamai. 27,5 proc. $(n=14)$ tiriamujų nerimą patyrẻ kartais, 
joms buvo sunkiau ji kontroliuoti, tačiau tai nedare didelès itakos jų kasdieniam gyvenimui. 13,7 proc. $(n=7)$ respondenčių nurodè, kad nerimą patiria dažnai, ji darosi sunku kontroliuoti. Viena moteris teigè, kad nerimą jaučia beveik visada, negali jo suvaldyti ir tai trukdo jos kasdieniam gyvenimui. Detaliau nerimo simptomai pavaizduoti 3 paveiksle.

Statistiškai patikimai nustatyta, kad motinos patirtam nerimui ịtakos turi šeiminè padètis, žinojimas iš anksto apie gresiantị priešlaikini gimdymą, patirta įtampa, baimè, širdies ir kraujagyslių simptomai $(\mathrm{p}<0,05)$.

İtampa. 45,1 proc. $(n=23)$ respondenčiu anketoje pažymejjo, kad yra šiek tiek nervingesnès, daugiau ịsitempusios nei paprastai. 15,7 proc. $(n=8)$ moterų teigè negalinčios atsipalaiduoti, joms sunku kontroliuoti vidinị neramumą, tačiau tai dar neturi didelès įtakos jų kasdieniam gyvenimui. 3,9 proc. $(\mathrm{n}=2)$ tiriamujjų dažnai patyre ịtampą, nervingumą ir tai retkarčiais trukdè jų kasdieniam gyvenimui. 3,9 proc. $(n=2)$ gimdyvių teigè, kad įtampa ir neramumas išlieka nuolat. Detaliau ịtampos simptomai pavaizduoti 3 paveiksle.

Itampai itakos turi patirtas nerimas, baimé, depresija, širdies ir kraujagyslių bei raumenų simptomai $(\mathrm{p}<0,05)$.

Baimè. 5,9 proc. $(n=3)$ respondenčių nurodé, jog jaučia nedidelę baimę, tačiau joms pavyksta ją įveikti. 7,8 proc. $(\mathrm{n}=4)$ tiriamujų teigia, kad patiria baimę ir tai šiek tiek trukdo kasdienei jų veiklai. 3,9 proc. $(n=2)$ respondenčių nurodè, jog baimè dèl priešlaikinio gimdymo labai trukdè pastaruoju laikotarpiu. Detaliau baimès simptomų pasireiškimas pavaizduotas 3 paveiksle.

Nustatytas statistiškai patikimas ryšys tarp baimès ir patirto nerimo, įtampos, sensorinių, raumenų, širdies ir kraujagyslių simptomų $(\mathrm{p}<0,05)$.

Nemiga. 25,5 proc. $(n=13)$ moterų miego kokybė pablogèjusi, miegas šiek tiek sutrikęs. 13,7 proc. $(\mathrm{n}=7)$ teigè, kad miego trukmè ir gilumas pakitę, per parą miega vos kelias valandas su pertraukomis. 11,8 proc. $(\mathrm{n}=6)$ gimdyvių buvo sunku nustatyti miego trukmę, nes miegas negilus, trumpi snaudimo ir numigimo periodai, sutrikusi miego trukmè ir kokybè. Išsamiau nemigos simptomai pateikti 4 paveiksle.

Sveikatos būklè, nèštumų skaičius, daugiavaisis nėštumas bei depresija turi reikšmingos įtakos moterų nemigai $(\mathrm{p}<0,05)$.

Susikaupimo ir atminties sunkumai. 17,6 proc. $(n=9)$ tiriamujų nurodè, kad kartais sunkiau susikaupti, tam reikia pastangų, tačiau tai kontroliuojama. 9,8 proc. $(\mathrm{n}=5)$ gimdyvių dažnai sunku susikaupti, nelengva prisiminti tam tikrus dalykus, sunkiau priimti sprendimus ir tai jom dažnai trukdo iprastinei veiklai. Detaliau susikaupimo ir atminties sunkumai charakterizuoti 4 paveiksle.

Rastas statistiškai patikimas ryšys tarp susikaupimo ir atminties sunkumų ir vegetacinių simptomų $(p<0,05)$.
Depresinè nuotaika. 23,5 proc. $(\mathrm{n}=12)$ moterų teigè esančios susirūpinusios, šiek tiek labiau prislègtos nei ịprastai. Viena moteris anketoje nurodè, kad yra dažniau nuliūdusi, dažniau apima tuštumo, nusivylimo jausmas. Detaliau depresinès nuotaikos pasireiškimas pateiktas 4 paveiksle.

Moterų sveikatos būklè, patirta įtampa, nemiga, raumenų, širdies ir kraujagyslių simptomai turi reikšmingos įtakos depresinei nuotaikai $(\mathrm{p}<0,05)$.

Raumenų simptomai. 9,8 proc. $(\mathrm{n}=5)$ moterų skundžiasi raumenų silpnumu, sustingimu, maudimu, kuris kartais perauga ị tikrą skausmą. Viena gimdyvė teigia, kad raumenų skausmai šiek tiek trukdo kasdieniam gyvenimui. Viena moteris nurodo, kad raumenų skausmai jaučiami beveik nuolat ir tai jai trukdo. Išsamiau raumenų simptomai pateikti 5 paveiksle.

Gimdyvès sveikatos būklè ir vaikelio neišnešiotumas, patirta ịtampa, bamè, depresija, širdies simptomai bei vegetaciniai ir sensoriniai simptomai turi reikšmingos itakos raumenų simptomams $(\mathrm{p}<0,05)$.

Sensoriniai simptomai. 9,8 proc. $(n=5)$ tiriamujų teigia, kad kartais spaudimo ausyse pojūtis pereina ị ǔžimą, akyse - ị regejjimo sutrikimus, o odoje pasireiškia diegimas ar niežulys. Viena respondente nurodo, kad sensoriniai simptomai netgi dažnai trukdo kasdienei veiklai. Detaliau sensoriniai simptomai charakterizuoti 5 paveiksle.

Moters išsilavinimas, gyvenamoji vieta, patirta baimè, raumenų simptomai, kvèpavimo ir virškinimo simptomai turi reikšmingos įtakos sensoriniams simptomams $(\mathrm{p}<0,05)$.

Širdies ir kraujagyslių simptomai. 15,7 proc. $(n=8)$ moterų nurode kartais patiriančios širdies ir kraujagyslių simptomus (širdies „,̌okinèjimą“, „daužymąsi“", kraujagyslių tvinkčiojimą, skausmą krūtinèje), tačiau dar gali juos kontroliuoti. 3,9 proc. $(n=2)$ tiriamujų teigè, kad širdies ir kraujagyslių simptomus jaučia dažnai ir kartais sunku juos kontroliuoti, tai trukdo jų kasdieniam gyvenimui. Išsamiau duomenys pateikti 5 paveiksle.

Motinos sveikatos būklè, vaikelio neišnešiotumas, patirtas nerimas, itampa, baimé, depresija, kvépavimo ir raumenu simptomai turi reikšmingos įtakos širdies ir kraujagyslių simptomams $(\mathrm{p}<0,05)$.

Kvėpavimo simptomai. 17,6 proc. $(\mathrm{n}=9)$ tiriamųų nurodè kartais patiriančios dusuli ar oro trūkumą, tačiau galinčios tai kontroliuoti. 3,9 proc. $(n=2)$ teige dažnai patiriančios šiuos simptomus, kartais sunku juos kontroliuoti ir tai šiek tiek trukdo kasdieniam gyvenimui. Kvėpavimo simptomų pasireiškimas detaliau pavaizduotas 6 paveiksle.

Moters gyvenamoji vieta, nėštumų bei gimdymų skaičius, sensoriniai, širdies ir kraujagyslių simptomai turi reikšmingos įtakos kvépavimo simptomams $(\mathrm{p}<0,05)$.

Virškinimo simptomai. 21,6 proc. $(n=11)$ moterų skun- 
dèsi epizodiniais virškinimo simptomais, tačiau juos galèjo kontroliuoti pačios. 7,8 proc. $(n=4)$ pagimdžiusiujų anksčiau gimdymo termino teige dažnai jaučiančios virškinimo sistemos sutrikimų, kartais sunkiai kontroliuojamų ir netgi šiek tiek trukdančių kasdienei veiklai. Išsamiau duomenys pateikti 6 paveiksle.

Gimdymų skaičius, vegetaciniai ir sensoriniai simptomai turi reikšmingos įtakos virškinimo simptomams $(p<0,05)$.

Autonominiai (vegetaciniai) simptomai. 23,5 proc. $(n=12)$ gimdyvių jaute vieną ar kelis autonominius simptomus (burnos džiūvimą, veido raudonị ar pabalimą, prakaitavimą bei galvos svaigimą), tačiau tai netrukdè kasdieniam gyvenimui. 7,8 proc. $(n=4)$ moterų nurodè, kad kartais jaučia kelis autonominius simptomus, kurie šiek tiek trukdo ịprastai veiklai. Šie simptomai detalizuoti 6 paveiksle.

Susikaupimo ir atminties sunkumai, sensoriniai simptomai, raumenų ir virškinimo simptomai turi reikšmingos įtakos autonominiams simptomams $(\mathrm{p}<0,05)$.

Bendri Hamiltono nerimo skalės balai. Gimdyvių, vertintu pagal Hamiltono nerimo skalę, vidurkis buvo 10,45 balai (min -0 , max -28 balai). Psichinio nerimo vidurkis 6,7 balai, somatinio $-4,14$. 76,5 proc. $(\mathrm{n}=39)$ moterų turi lengvą nerimo sutrikimą, 11,8 proc. $(\mathrm{n}=6)$ - vidutinio sunkumo, 11,8 proc. $(\mathrm{n}=6)$ - stiprų nerimo sutrikimą (7pav.).

Psichiatriné anamnezė. Praeityje pagalbos ị psichologus, psichiatrus ar psichoterapeutus buvo kreipusios 9,8 proc. $(n=5)$ tiriamujjų. Šių konsultacijų priežastys: jau anksčiau patirtas nerimas nèštumo metu, emocinis nestabilumas, netektys ir ịtampa. 7,8 proc. $(\mathrm{n}=4)$ gimdyvių yra vartoję vaistus, paskirtus gydytojo psichiatro (alprazolamą, sertraliną, pregabaliną, homeopatini preparatą Nervoheel).

Psichologo poreikis postnataliniu laikotarpiu. 25,5 proc. $(n=13)$ moterų teigia, kad joms žinių apie priešlaikini gimdymą, suteiktų medicinos personalo, nepakanka. 17,6 proc. $(\mathrm{n}=9)$ gimdyvių norètų psichologo konsultacijos pogimdyminiu laikotarpiu: 55,5 proc. $(\mathrm{n}=5)$ respondenčių užtektų vieno karto per savaitę, 44,5 proc. $(\mathrm{n}=4)$ pageidautų kas antrą dieną.

\section{Rezultatų aptarimas}

2014 m. panašiame atliktame tyrime, naudojant HADS nerimo skalę, 75 proc. prieš laiką pagimdžiusių moterų buvo nustatyta padidèjusi nerimo rizika, kitame $2014 \mathrm{~m}$. darytame tos pačios tematikos tyrime, naudojant IES, GHQ ir STAI skales, 17 proc. moterų diagnozuotas nerimo sutrikimas $(5,18)$. Šiame tyrime, naudojant HAM-N skalę, nerimo simptomas buvo vidutiniškai išryškejjęs ar netgi labai stipriai, trukdantis funkcionavimui - 43,2 proc. moterų.

Itampos simptomas buvo vidutiniškai išryškèjęs ar netgi labai stipriai, trukdantis funkcionavimui - 23,5 proc. moterų. 2016 m. tyrimo metu, naudojant POMS skalę, buvo lygintos moterys, gimdžiusios laiku, su prieš laiką pagimdžiusiomis - nustatyta, kad moterys, pagimdžiusios anksčiau gimdymo termino, statistiškai dažniau patiria įtampą (19).

Depresinè nuotaika buvo vidutiniškai išryškejjusi ar netgi labai stipriai, trukdanti funkcionavimui - 25,5 proc. gimdyvių. $2014 \mathrm{~m}$. atliktame panašiame tyrime, naudojant IES, GHQ ir STAI skales, 28 proc. prieš laiką pagimdžiusių moterų buvo diagnozuota depresija (18). Kito $2014 \mathrm{~m}$. tyrimo išvados, naudojant HADS nerimo skalę, teigia, kad 39 proc. moterų buvo nustatyta padidejusi depresijos rizika (5).

Atlikta ne viena studija, įrodanti, jog prieš laiką pagimdžiusios motinos patiria didesni stresą $(5,7,16,18,20)$, tačiau visuose mokslo darbuose yra naudotos skirtingos metodinès analizės, tad yra sunku lyginti tyrimų rezultatus.

Labai nedaug yra mokslinių tyrimų, nagrinèjančių gimdyvių psichikos sveikatos sutrikimų sukeliamus somatinius simptomus, tad šiame darbe buvo vertintas ne tik psichinis, bet ir somatinis nerimas.

HAM-N skalè buvo kritikuojama, nes ne visada atskiria tiriamuosius su nerimo simptomais nuo tiriamujų su depresijos simptomais (žmonèms su depresija taip pat būdingi aukšti HAM-N skalès įvertinimai), tačiau kai kurie mokslininkai teigia, jog nerimas ir depresija yra taip glaudžiai susiję, kad tiriamieji gali rodyti aukštus abiejų tipų simptomų îvertinimus (17).

25,5 proc. mūsų tirtu gimdyvių teige, jog joms nepakanka žinių apie priešlaikini gimdymą, gautų iš medicinos personalo. Užsienio literatūroje teigiama, kad moterys, kurioms buvo suteikta nepakankamai demesio ar informacijos apie gimdymo eigą, patiria didesni stresą (22). 17,6 proc. prieš laiką pagimdžiusių moterų norètų, kad joms būtų suteikta psichologo konsultacija pogimdyminiu laikotarpiu. Atsižvelgus ị bendrą HAM-N skalès vidurkị, net 23,6 proc. tiriamujų nustatytas vidutinio sunkumo ar stiprus nerimo sutrikimas, tad psichologo poreikis yra didesnis nei teigia pačios gimdyvès. 2014 m. atlikto panašaus tyrimo metu, atsižvelgus i gautus rezultatus, net 30,1 proc. prieš laiką pagimdžiusių moterų buvo pasiūlyta psichologo konsultacija (5).

\section{Išvados}

1. 70 proc. gimdyvių patiria emocinių sukrètimų dèl priešlaikinio gimdymo. 76,5 proc. prieš laiką pagimdžiusių moterų diagnozuotas lengvas nerimo sutrikimas, 11,8 proc. - vidutinio sunkumo ir 11,8 proc. - stiprus nerimo sutrikimas.

2. Šeiminè padètis turi įtakos patiriamam nerimui perinataliniu laikotarpiu, išsilavinimas - sensoriniams simptomams, gyvenamoji vieta - kvėpavimo ir sensoriniams simptomams.

3. Bloga motinos sveikatos būklè didina nemigos, depresinès nuotaikos, raumenų bei širdies ir kraujagyslių simptomų riziką. 
4. Nèštumų skaičius turi įtakos nemigai ir kvėpavimo simptomams, o gimdymų skaičius - kvejpavimo ir virškinimo simptomams. Daugiavaisis nëštumas turi įtakos nemigai.

5. Vaikelio neišnešiotumas gali lemti raumenų simptomų bei širdies ir kraujagyslių simptomų atsiradimą.

6. Psichinio nerimo simptomai turi įtakos somatinio nerimo simptomams atsirasti.

7. 17,6 proc. tiriamujų norètų psichologo konsultacijos po gimdymo: 55,5 proc. užtektų vieno karto per savaitę, 44,5 proc. - kas antrą dieną. Tyrimo rezultatai parodè, kad psichologo poreikis yra didesnis nei teigia pačios gimdyvès.

\section{Literatūra}

1. Blencowe H, Cousens S, Oestergaard M, Chou D, Moller AB, Narwal R. et al. National, regional and worldwide estimates of preterm birth. The Lancet June 2012; 9;379(9832):216272. Prieiga per internetą: http://www.who.int/mediacentre/ factsheets/fs363/en/

2. Blencowe H, Cousens S, Chou D, Oestergaard M, Say L, Moller AB. et al. Born too soon: the global epidemiology of 15 million preterm births. Reproductive Health 2013; 10(Suppl 1):S2 Prieiga per internetą: https://www.ncbi.nlm.nih.gov/pmc/ articles/PMC3828585/

3. Abraitis V., Arlauskienė A., Bagušytė L., Barčaitè E., Bartkevičienè D., Biržietis T. ir kt. Priešlaikinio gimdymo metodika, $2014 \mathrm{~m}$

4. Joseph KS, Fahey J, Shankardass K, Allen VM, O`Campo P, Dodds L. et al. Effects of socioeconomic position and clinical risk factors on spontaneous and iatrogenic preterm birth. BMC Pregnancy Childbirth 2004;14:117 Prieiga per internetą: https:// www.ncbi.nlm.nih.gov/pubmed/24670050

5. Eutrope J, Thierry A, Lempp F, Aupetit L, Saad S, Dodane C. et al. Emotional reactions of mothers facing premature births: study of 100 mother-infant dyads 32 gestational weeks. PLoS One 2014; 9(8): e104093 Prieiga per internetą: https://www. ncbi.nlm.nih.gov/pmc/articles/PMC4143228/

6. Astolfi P, Zonta LA. Risks of preterm delivery and association with maternal age, birth order, and fetal gender. Human Reproduction 1999; 14(11): 2891-2894. Prieiga per internetą: https:/academic.oup.com/humrep/article/14/11/2891/860109/ Risks-of-preterm-delivery-and-association-with

7. Sekizuka-Kagami N, Shimada K, Tabuchi N, and Nakamura H. Association between the sense of coherence 13-item version scale score of pregnant women in the second trimester of pregnancy and threatened premature birth. Environmental Health and Preventive Medicine 2015 Mar; 20(2): 90-96. Prieiga per internetą: https://www.ncbi.nlm.nih.gov/pmc/ articles/PMC4597347/

8. Arck PC, Rücke M, Rose M, Szekeres-Bartho J, Douglas AJ, Pritsch M, Blois SM. et al. Early risk factors for miscarriage: a prospective cohort study in pregnant women. Reprod Biomed Online 2008 Jul; 17(1):101-13 Prieiga per internetą: https://www.ncbi.nlm.nih.gov/pubmed/18616898/
9. Mancuso RA, Schetter CD, Rini CM, Roesch SC, Hobel CJ. Maternal prenatal anxiety and corticotropin-releasing hormone associated with timing of delivery. Psychosom Med 2004 SepOct;66(5):762-9. Prieiga per internetą:

https://www.ncbi.nlm.nih.gov/pubmed/15385704/

10. Rice F, Jones I, Thapar A. The impact of gestational stress and prenatal growth on emotional problems in offspring: a review. Acta Psychiatr Scand 2007 Mar; 115(3):171-83. Prieiga per internetą: https://www.ncbi.nlm.nih.gov/pubmed/17302617/

11. Hilmert CJ, Schetter CD, Dominguez TP, Abdou C, Hobel CJ, Glynn L. et al. Stress and blood pressure during pregnancy: racial differences and associations with birthweight. Psychosom Med 2008 Jan;70(1):57-64.

Priega per internetą: https://www.ncbi.nlm.nih.gov/pubmed/18158373/

12. Field T, Yando R, Bendell D, Hernandez-Reif M, Diego M, Vera Y. et al. Prenatal depression effects on pregnancy feelings and substance use. Journal of Child \& Adolescent Substance Abuse 2007; 17:111-125. Priega per internetą: http://www. tandfonline.com/doi/abs/10.1300/J029v17n01_06

13. Kossakowska PK, Walecka MK. Psychological causative factors in postpartum depression amongst women with normal and high-risk pregnancies. Ginekol Pol 2007 Jul;78(7):544-8. Prieiga per internetą: https://www.ncbi.nlm.nih.gov/pubmed/17915411

14. Beebe B, Steele M, Jaffe J, Buck AK, Chen H, Cohen P. et al. Maternal anxiety symptoms and mother-infant self- and interactive contingency. Infant Ment Health J 2011 Mar-Apr; 32(2):174-206. Prieiga per internetą: https://www.ncbi.nlm. nih.gov/pmc/articles/PMC4431701/

15. Hobel CJ, Goldstein A, Barrett ES. Psychosocial stress and pregnancy outcome. Clin Obstet Gynecol 2008 Jun; 51(2):33348. Prieiga per internetą: https://www.ncbi.nlm.nih.gov/ pubmed/18463464/

16. Vigod SN, Villegas L, Dennis CL, Ross LE. Prevalence and risk factors for postpartum depression among women with preterm and low-birth-weight infants: a systematic review. BJOG 2010 Apr;117(5):540-50. Prieiga per internetą: https://www.ncbi. nlm.nih.gov/pubmed/20121831

17. Kaminskaitė T., Bunevičius R. Biologinè psichiatrija ir psichofarmakologija. Hamiltono nerimo skalè ir jos naudojimo galimybès. 2009 rugpjūtis; 11: 1.

18. Misund AR, Nerdrum P, Diseth HT. Mental health in women experiencing preterm birth. BMC Pregnancy Childbirth 2014; 14: 263. Priega per internetą: https://www.ncbi.nlm.nih.gov/ pmc/articles/PMC4137092/

19. Ionio C, Colombo C, Brazzoduro V, Mascheroni E, Confalonieri E, Castoldi F. et al. Mothers and Fathers in NICU: The impact of preterm birth on parental distress. Eur J Psychol 2016 Nov; 12(4): 604-621. Prieiga per internetą: https://www.ncbi.nlm. nih.gov/pmc/articles/PMC5114875/

20. Petit AC, Eutrope J, Thierry A, Bednarek N, Aupetit L, Saad 
S. et al. Mother's emotional and posttraumatic reactions after a preterm birth: the mother-infant interaction is at stake 12 months after birth. PLoS One 2016; 11(3): e0151091. Prieiga per internetą: https://www.ncbi.nlm.nih.gov/pmc/articles/ PMC4811536/

21. Wadhwa DP, Entringer S, Buss C. Lu CM. The contribution of maternal stress to preterm birth: issues and considerations. Clin Perinatol 2011 Sep; 38(3): 351-384. Prieiga per internetą: https://www.ncbi.nlm.nih.gov/pmc/articles/PMC3179976/

22. Paliulytė V., Zdanyte K., Žitkutė V. Veiksniai, turintys įtakos moters pasitenkinimui planiniu gimdymu ir planine cezario pjūvio operacija. Medicinos teorija ir praktika, 2016; 22(2).

\section{THE EVALUATION OF MENTAL STATE OF WOMAN WHO GAVE PRETERM BIRTH \\ A. Jurėnas, V. Paliulytė}

Key words: preterm birth, mental state, anxiety, HAM-A.

Summary

Object of the thesis is to evaluate mental state of women who gave preterm birth and to estimate a need of psychological consultations during postnatal period.

Materials and methods. Prospective anonymous questionnaire survey carried out at Vilnius University Hospital Santara clinic's, Center of Obstetrics and Gynecology during the period from November 2016 until February 2017. The survey encompassed 51 women who gave preterm birth. Questions of the survey were provided in postnatal wards in period of 1-3 days after giving birth. The main object was to evaluate mental state of the woman in regard to demographic data, obstetric histroy and pregnancy course. The main method for evaluation of mental and somatic anxiety was Hamilton anxiety scale (HAM-A) that was modified, discussed and approved by psychiatrist and obstetrician-gynecologist. Received data was processed with SPSS 20 program. Reliability of the data was calculated and evaluated with a help of Chi-Quadrat test $(\mathrm{p} \leq 0.05)$.

Results. $68.6 \%(\mathrm{~s}=35)$ of women stated that they have suffered emotional distress due to preterm birth. According to respondents, the biggest impact for overall metal state during perinatal period was anxiety $(60.8 \%,(\mathrm{~s}=31)$, fear $(13.7 \%,(\mathrm{~s}=7)$, insomnia $(13.7$ $\%,(s=7)$ and tension $(11.8 \%,(s=6)$. Average score of questioned women (according to Hamilton anxiety scale) was 10.45 ( $\mathrm{min}-0$; $\max -28$ scores). Average number of metal anxiety -6.7 scores, average number of somatic anxiety -4.14 scores. $76.5 \%(s=39)$ of questioned women have mild anxiety disorder (collected up to 14 scores $), 11.8 \%(s=6)$ of women have moderate anxiety disorder (collected from 15 up to 21 scores) and $11.8 \%(\mathrm{~s}=6)$ of women have severe anxiety disorder (collected more than 21 scores). $17.6 \%(\mathrm{~s}=9)$ of investigated women claim that during postnatal period they would prefer to have psychological consultation: 55 $\%(\mathrm{~s}=5)$ of women who recently gave preterm birth would like to have consutation once a week and $44.5 \%(\mathrm{~s}=4)$ would like to consult psychologist every other day.

Conclusion. Even $23.6 \%$ of women who have recently gave a preterm birth suffered from moderate or severe anxiety disorder. Separate mental and somatic anxiety symptoms are impacted by particular demographic data, factors of obstetric histroy and consequences of pregnancy course. The results have revealed that even $17.6 \%$ of respondents would prefer to have postnatal psychological consultation.

Correspondence to: jurenasandrius@gmail.com

Gauta 2017-05-24 